\title{
HYGIENIC ASPECTS OF LIFESTYLE OF KHARKIV NATIONAL MEDICAL UNIVERSITY JUNIOR STUDENTS IN THE CONDITIONS OF QUARANTINE
}

DOI: 10.36740/WLek202103232

\author{
Volodymyr 0. Korobchansky, Yuliia 0. Oliinyk, Valentyna G. Nesterenko, Vladyslava V. Sarkis-Ivanova, Olena V. Hryhorian \\ KHARKIV NATIONAL MEDICAL UNIVERSITY, KHARKIV, UKRAINE
}

\begin{abstract}
The aim: To assess the impact of adverse factors on the lifestyle and health status of students in conditions of prolonged isolation.

Materials and methods: Data collection was carried out by anonymous survey using the survio.com online survey service. The study involved 273 students of Kharkiv National Medical University: 47 men (17,2\%) and 226 women (82,8\%) aged 17 to 20 . Age of $85 \%$ of respondents is 18 -20 years old. $38(13,9 \%)$ students are from 21 to 25 years old and 3 students $(1,1 \%)$ - over 25 years old.

Results: A comparative analysis revealed the characteristic changes in the students' lifestyle. If under normal conditions the majority of students (63.7\%) use their free time for walks outdoors, and $46.5 \%$ spend it at the computer, then during quarantine most respondents spend leisure time in front of a computer monitor (64.8\%) or watching TV (71.4\%). These indices were the result of a direct restriction on the interaction of students with the environment and the prohibition of their stay outside the zone of residence. Conclusions: The most common negative changes of the students' health were sleep disturbances and headaches. The second most common symptoms are changes in the musculoskeletal system, associated mainly with physical inactivity. The third ones are deterioration of vision and psycho-emotional state of students.
\end{abstract}

KEY WORDS: COVID-19, students, lifestyle, distance learning, Kharkiv National Medical University

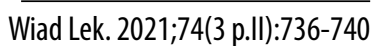

\section{INTRODUCTION}

The COVID-19 virus pandemic has made adjustments to the lives of people around the world and put them in certain conditions of existence. Mankind is faced with a situation where it is necessary to clearly follow certain rules to curb the spread of the virus. Ukraine, as well as other countries around the world, has introduced a quarantine regime.

The concept of "quarantine" provides for restrictions on movement, as well as identification of people who are prone to contagious disease, to further clarify whether they have contracted it. Thus, the risk of spreading the virus is reduced. Quarantine, from a medical point of view, is very effective in protecting the population from the spread of the disease [1]. The restriction of movement, the introduction of an observational regime after travel, the prohibition of visits to parks, squares, recreation areas in the future will lead to positive consequences for overall health [2].

Studies of different years, by interviewing, described subjects who were in quarantine and, in general, the indices of health disorders coincided. According to the results of some studies, there were mental health disorders. Mihashi M. mentions such symptoms as general emotional distress in quarantined people [3]. The state of depression and stress was evaluated by Austrian researchers, the frequency of depression cases increased four times [4]. Long-term mood decline, insomnia, and increased irritability were described by Lee $\mathrm{S}$. in his studies $73 \%$ of respondents showed a decrease in mood, $57 \%$ of respondents noted irritability [5].

Assessing the results by Weiss and Marmar impact of event scale, Reynolds D. L., Garay J. R. identified symptoms of post-traumatic stress [6].

Most of the negative consequences were due to restrictions on freedom of movement and communication. Thus, it has been established that the general state of health is always reflected in all spheres of life [7].

The intensity of various processes directly depends on the level of health, qualitatively characterizes a person's lifestyle: levels of economic, labor, social activity. Health is one of the most important conditions for the quality of human performance [8].

Attention to the lifestyle of students during the quarantine period is associated with high public concern about the health of specialists graduating from higher educational institutions [9].

One of the determining factors of a healthy lifestyle is optimal physical activity, which directly depends on the routine of the working day, domestic needs and the rational distribution of free time. However, since the beginning of 2020 , there have been numerous adverse factors, including isolation conditions, which contributed to an increase in psycho-emotional stress with reduced physical activity. 


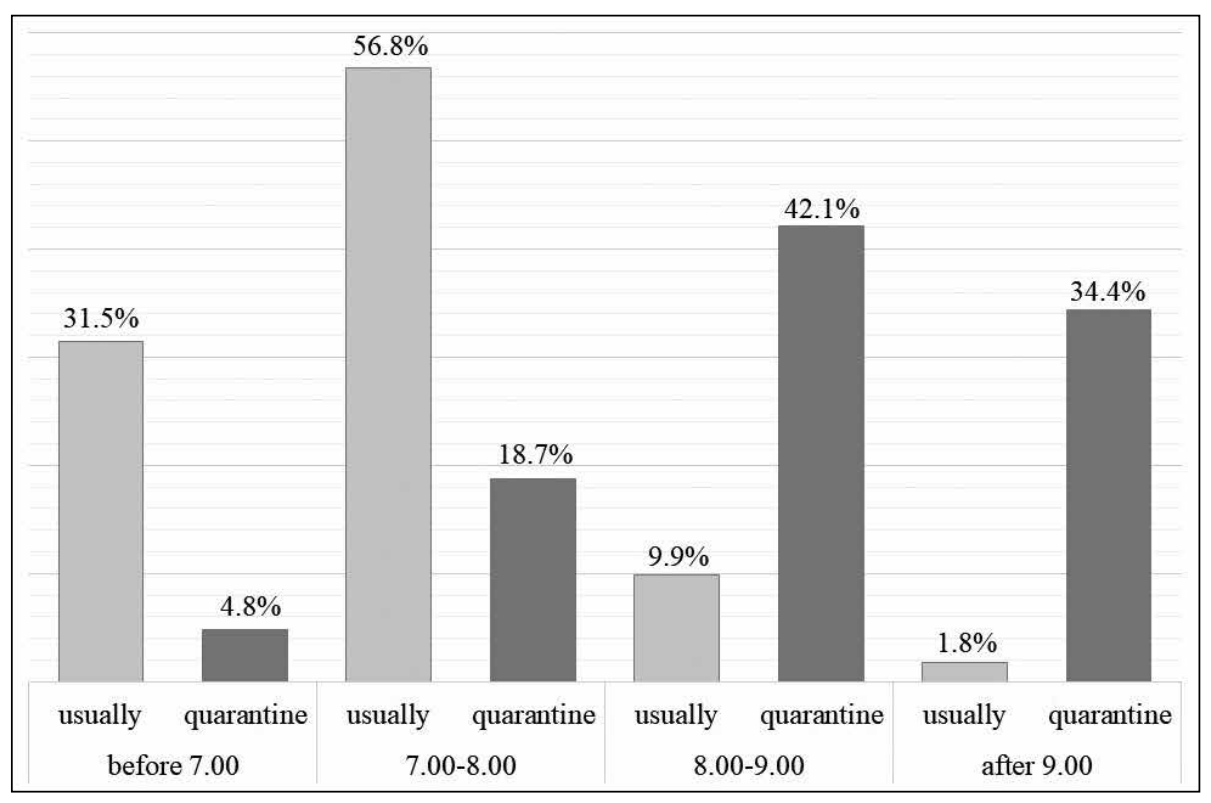

Fig. 1. Indices of changes in the time of morning awakening of students
Teachers of Kharkiv National Medical University are also concerned about the health status of future doctors, substantiating the need for a study. The study revealed various negative trends in students' lifestyle changes.

\section{THE AIM}

The aim was to assess the impact of adverse factors on the lifestyle and health status of students in conditions of prolonged isolation.

\section{MATERIALS AND METHODS}

Data collection was carried out by anonymous survey [12] using the survio.com online survey service. The study involved 273 students of Kharkiv National Medical University aged 17 to 20 . The questionnaire contained questions that characterize the students' lifestyle (leisure activities, playing sports, spending time outdoors), day regimen (distribution of work and rest hours, sleep and wakefulness regimen, and nutritional regimen), the features of organizing distance learning in quarantine (organization of workspace and type of digital device that is primarily used for online learning, the time spent on homework), changes in the physical and psycho-emotional state (subjective characteristics of students' health status, the presence of symptoms such as fatigue, blurred vision, headaches, sleep disturbance, distraction, anxiety, depression).

\section{RESULTS}

A comparative analysis of the data revealed the characteristic changes in the daily routine and lifestyle of students before and during quarantine. Thus, if under normal conditions the majority of students (63.7\%) use their free time for walks outdoors, and $46.5 \%$ spend it at the computer (communication on social networks, computer games, etc.), then during quarantine most respondents spend leisure time in front of a computer monitor (64.8\%) or watching television programs and films (71.4\%). These indices were the result of a direct restriction on the interaction of students with the environment and the prohibition of their stay outside the zone of residence. A long stay in a confined space with a limited area of movement leads to physical inactivity and hypokinesia, which in turn can lead to a number of disorders of many functions and systems of the body. Most negatively this affects students with a low level of self-organization who do not pay due attention to their physical development and do not play sports. According to the results of the survey, $34.4 \%$ of students do not go in for sports and do not exercise at home. $32.9 \%$ went in for sports and visited a gym until isolation, but their number was almost halved, and they completely stopped any sports during quarantine (15.0\%).

Most students $(57.9 \%)$ note changes in the nature of nutrition, in the direction of increasing the frequency of food intake and its volume. The increase in body weight observed by $39.2 \%$ of respondents in combination with physical inactivity / hypokinesia can lead to functional disorders of the musculoskeletal, vestibular and sensorimotor apparatus. At the same time, there is a direct relationship of motor activity and the nature of nutrition with metabolic processes, which can lead to disruption of processes in the endocrine system.

An important factor in this case is also the correct organization of the workspace, taking into account the basic principles of ergonomics. $85.3 \%$ of respondents indicated that they have a separate specially equipped workplace. However, distance learning can imply the employment of fundamentally different electronic devices (desktop computer, tablet, smartphone and others). Working on a personal computer is mainly carried out at a specially equipped workplace, while working on a smartphone and other small devices does not require any special conditions. According to the survey, $48 \%$ of students use a computer for learning. The remaining $52 \%$ work with smartphones and tablets, while ergonomic and hygiene requirements are most often not respected. 

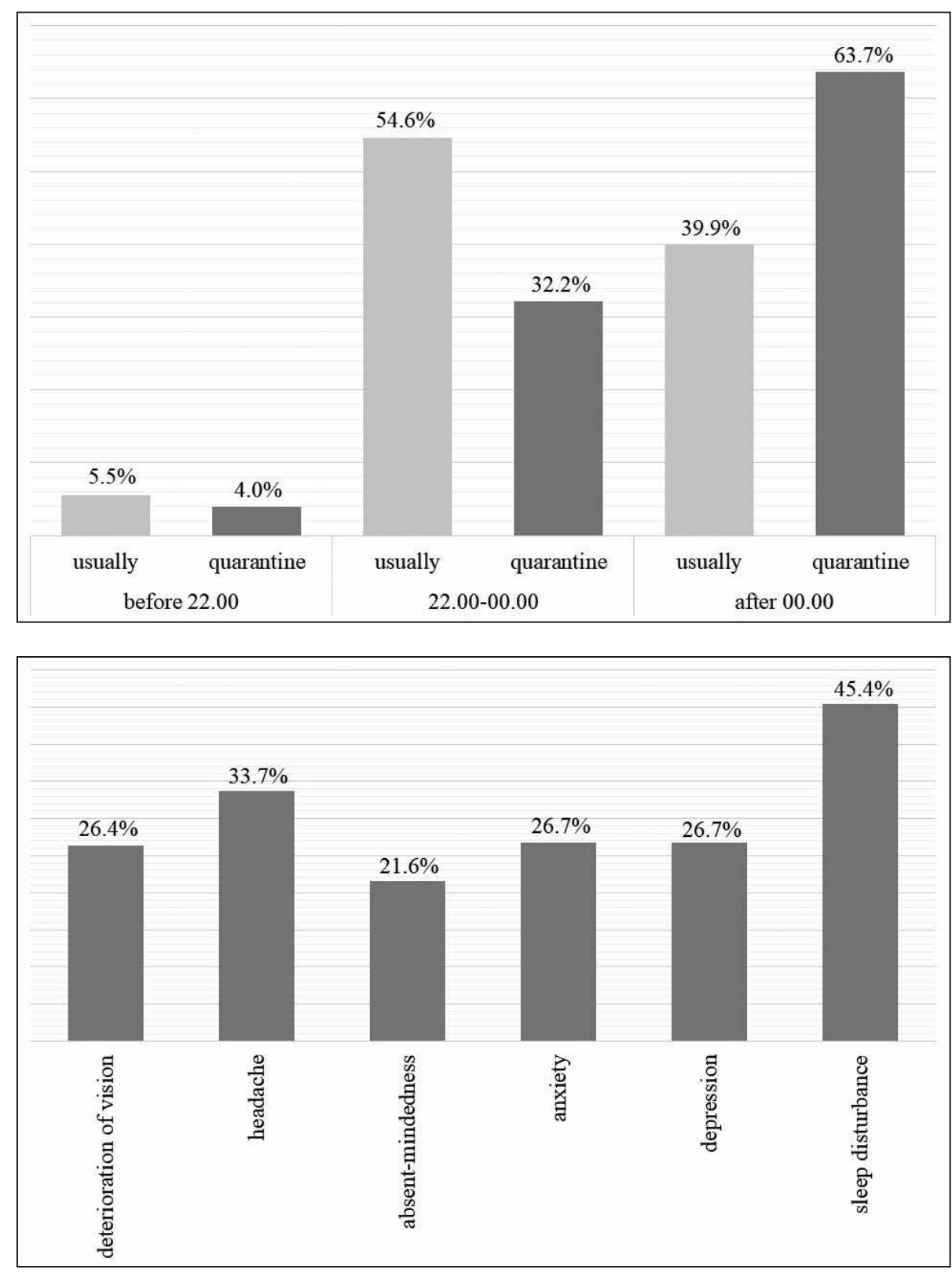

Fig. 2. Indices of changes in the evening bedtime of students
Fig. 3. Indices of changes in the physiological and psychological state of students
Typical symptoms in a decrease in motor activity and a long stay in an uncomfortable position are pain and tension in the back, which was noted by $29.7 \%$ of respondents. $27.5 \%$ of students indicated a decrease in muscle strength, $43.6 \%$ noted increased fatigue.

Assessment of daily regimen and working capacity showed insignificant fluctuations of biorhythms with a tendency to increase the number of students with evening type of working capacity. Daily routine of respondents markedly shifted towards a later awakening in the morning and late going to bed (Fig. 1).

As can be seen from the chart, the percentage of respondents who wake up earlier than 7 am and from 7.00 to 8.00 decreased from $31.5 \%$ to $4.8 \%$ and from $56.8 \%$ to $18.7 \%$, respectively. The number of students who sleep in the morning until $8.00-9.00$ and longer during quarantine significantly increased. Their percentage increased from $11.7 \%$ to $76.5 \%$. The percentage of respondents who go to bed late also increased (Fig. 2).

$54.6 \%$ went to bed in the interval from 22.00 to 24.00 before quarantine, and $46.9 \%$ during quarantine. The number of students awake until midnight and later increased from $39.9 \%$ to $63.7 \%$. The change in the student's day regimen can be explained by a change in biorhythms aimed at maintaining homeostasis under the influence of adverse external factors. To a greater extent, these changes occurred due to restrictions on movement.

Changes in day regime and lifestyle with prolonged and forced exposure to a number of adverse factors under quarantine lead to changes in both the physiological and psychological state of students. The results of the survey revealed that during the isolation period, students developed the following symptoms: sleep disturbance in $45.4 \%$ of respondents, headaches in $33.7 \%$, deterioration of vision in $26.4 \%$. Depression and anxiety developed in $26.7 \%$ of respondents, absent-mindedness in $21.6 \%$ (Fig. 3 ) 
The above symptoms are determined by stress associated with space limitations and inactivity / hypokinesia during the isolation period, an abundance of numerous negative information about the pandemic from the media and the Internet, a forced restructuring of the daily regimen, changes in the nature and frequency of nutrition, and a sharp restructuring from the full-time education system to distance learning system and as a result, an increased amount of time for working with various information resources.

\section{DISCUSSION}

As the results of the study showed, the lifestyle of Kharkiv National Medical University students has undergone certain changes because of the COVID-19 pandemic. These changes are primarily related to forced isolation. Scientists from different countries found out that the most frequent companions of social isolation are psycho-neurological disorders: a deterioration in a person's mood, a feeling of loneliness, vulnerability, the appearance of anxiety and fears, including fear of infection, many people develop severe symptoms of depression. These changes lead to a decrease of cognitive abilities, memory, concentration of attention. The most common neurological symptoms are sleep disturbances and headaches. $[3,4,6,7,13,14]$. Moreover, in young people, these symptoms are more pronounced. Similar disturbances were revealed during a survey of students of Kharkiv National Medical University: sleep disturbance noticed $45.4 \%$ of respondents, headaches $-33.7 \%$, depression and anxiety developed in $26.7 \%$ of respondents, absent-mindedness in $21.6 \%$ ( $\mathrm{p}>0,05)$.

Distance learning is the second equally important factor that influencing the lifestyle of students during the quarantine period. Most often changes of daily routine and habits are: a decrease in physical activity, changes in sleep and wake regimen $[7,13,15]$ and changes of diet. It has been proven that increased release of cortisol in humans organism as a result of prolonged stress increases appetite [16]. These changes may lead to disorders of the musculoskeletal, cardiovascular and nervous systems, overweight. Within 60 days of quarantine $27.5 \%$ of students indicated a decrease in muscle strength, $43.6 \%$ noted increased fatigue $(\mathrm{p}>0,05)$, the increase in body weight observed by $39.2 \%$ of respondents. The changes become more pronounced in case of prolonged quarantine restriction.

\section{CONCLUSIONS}

Assessment of the students' survey findings showed that despite the indisputable advantages of training using information technologies in recent years, this system also has a number of drawbacks that became most obvious under quarantine and the forced transition of educational institutions to full-time distance learning.

The most common manifestations of the negative impact on the health of students of this educational system are sleep disturbances and headaches. This might be associated with a change in the day regime, physical inactivity, irrational organization of the workplace and time, information overload.

The second most common symptoms are changes in the musculoskeletal system, associated mainly with physical inactivity.

The third ones are deterioration of vision and psycho-emotional state of students.

The main role in the prevention of identified health disorders belongs to the student himself, who must properly organize his workplace, strictly observe the regime of work and rest, regularly perform a set of exercises for both the musculoskeletal system and the eyes. It also depends a lot on the social conditions and material capabilities of the student (the higher the quality of electronic devices used for work, the less their adverse effect on health).

Negative changes in the student's psycho-emotional state can be minimized by the employment in the learning process of dynamic, easy-to-perceive techniques, involving the change of different types of activities, collective solution of certain problems with the participants communicating in real time, the use of educational games and simulations, etc.

\section{REFERENCES}

1. Manuell M-E., Cukor J. Mother Nature versus human nature: public compliance with evacuation and quarantine. Disasters. 2011;35:417-442.

2. LiX., Zhao X., Sun Y. The lockdown of Hubei Province causing different transmission dynamics of the novel coronavirus (2019-nCoV) in Wuhan and Beijing medRxiv.2020. doi: https://doi.org/10.1101/2020.02.09.2 0021477.

3. Mihashi M.,Otsubo Y.,Yinjuan X. Predictive factors of psychological disorder development during recovery following SARS outbreak. Health Psychol. 2009;28:91-100.

4. Samozhnev A. Uchenye opredelili naibolee postradavshih ot karantina. 2020. https://rg.ru/2020/05/06/uchenye-opredelili-naiboleepostradavshih-ot-karantina.html

5. Lee S.,Chan L.Y.,Chau A.M.,Kwok K.P. The experience of SARS-related stigma at Amoy Gardens.Soc Sci Med. 2005;61:2038-2046.

6. Reynolds D.L., Garay J.R., Deamond S.L., Moran M.K. Understanding, compliance and psychological impact of the SARS quarantine experience. Epidemiol Infect. 2008;136:997-1007.

7. Blinova E.G. Prichinno-naslidkovi zvjazki v sisteme vtraty zdorovja studentiv. Materials Vseros. Nauchno-practicheskoy konferencii s mezhdunarodnim uchastiem « Gigiena detey I podrostkov istorija I sovremennost (problemy I puti reshenija)». Nauchniy cenrt zdorovja detey i podrostko.v RAMN. 2009:57-59.

8. Pro problemy globalnoy strategii WHO po dosjagnennjy zdorovja dlja vsih v XXI veke. //Pitannja economiki I upravlinnja dlja precivniciv ohorony zdorovja. 2002; 4:2-37.

9. Gorbach N.A., Zharov A.V., Lisnjak M.A. Perspectivy vikoristannja metodu ocinki jakosty zhittja u formuvanni zdorovja ctudentiv vishiv. Ochorona zdorovja Rossiyskoi federacii. 2007;2:43-46.

10. COVID-19 i prava cheloveca. 2020. https://www.hrw.org/ru/ news/2020/04/01/340211.

11. Hawryluck L., Gold W.L., Robinson S. SARS control and psychological effects of quarantine, Toronto, Canada. Emerg Infect Dis. 2004;10:12061212. 
12. Oprosnick dlja ocenki izmeneniy zhiznedejatelnosti studentov v uslovijah isoljacii. http://www.knmu.kharkov.ua/index.php?option=com_ content\&view=article\&id=148\%3A-1.

13. Khasuev A.E. Social insulation and human self-insulation: socialphilosophical analysis. Economical and humanitarical researches of the regions. 2020;2:122-128.

14. Mohammad S., Oakeshott R.P., Kankam H. et al. Mitigating the psychological effects of social isolation during the covid-19 pandemic .BMJ. 2020; 369. doi: https://doi.org/10.1136/bmj.m1904.

15. Oliinyk Y., Nesterenko V. Vplyv dystanciinogo navchannia na styl zhyttia inozemnyh studentiv. Materialy konferencii MCND. 2020: 73-74. https:// doi.org/10.36074/22.05.2020.v2.08

16. Ahmed M. Abbas Mark Mohsen Kamel Dietary habits in adults during quarantine in the context of COVID-19 pandemic. Obesity Medicine. 2020;19:100254. doi: 10.1016/j.obmed.2020.100254.

\section{ORCID and contributionship:}

Volodymyr O. Korobchansky: 0000-0002-8118-6884 ${ }^{\text {E, F }}$

Yuliia O. Oliinyk: 0000-0003-3214-0422 B,D

Valentyna G. Nesterenko: 0000-0002-3773-9525 A, E

Vladyslava V. Sarkis-Ivanova: 0000-0002-3953-550X ${ }^{\text {A, C }}$

Olena V. Hryhorian: 0000-0002-2906-7239 C, D

\section{Conflict of interest:}

The Authors declare no conflict of interest.

\author{
CORRESPONDING AUTHOR \\ Yuliia 0. Oliinyk \\ Kharkiv National Medical University \\ 4 Nauki av., 61000 Kharkiv, Ukraine \\ tel: $+380-50-5785385$ \\ e-mail:yulchonok78@gmail.com
}

Received: 28.11 .2020

Accepted: 11.03.2021

A - Work concept and design, B - Data collection and analysis, C - Responsibility for statistical analysis,

D-Writing the article, $\mathbf{E}$-Critical review, $\mathbf{F}$ - Final approval of the article 